\title{
Foreign Direct Investment, Portfolio Investment, and Economic Growth in Indonesia: Vector Auto Regression Approach
}

\author{
Marzuki ${ }^{1}$, Wahyuddin Albra ${ }^{2}$, Nazir ${ }^{1}$, Fahmy Azhari ${ }^{1}$, Apridar Abdurrahman ${ }^{1}$ and Ghazali \\ Syamni ${ }^{1,3}$ \\ \{marzuki_unimal@yahoo.com\} \\ ${ }^{1}$ Departement of Management, Faculty of Economic and Business, Universitas Malikussaleh, Aceh, \\ Indonesia \\ ${ }^{2}$ Departement of Accounting, Faculty of Economic and Business, Universitas Malikussaleh, Aceh, \\ Indonesia \\ ${ }^{3} \mathrm{PhD}$ Scholar in Doctorate Management Programme, Faculty of Economic and Business, University \\ Syiah Kuala, Indonesia
}

\begin{abstract}
The goal of this research is to examine the Foreign Direct Investment (FDI), Portfolio Investment (PI) and Economic Growth (EG) correlation in Indonesia. This research is using the Economic growth, foreign direct investment and portfolio investment data during 2010-2016, which is accessed from www.bps.go.id; www.bkpm.go.id and www.bi.go.id, and using Vector Auto Regression method. The result shows that FDI and EG have two way correlationship, meaning the connection between past Indonesia FDI and recentIndonesia EG are exist. PI and EG have the same correlationship yet it does not influence the investors to invest at the Indonesia Stock Exchange, as they, particularly foreign investors, are looking forward to the Indonesia Macroeconomy policies or recent information about it.
\end{abstract}

Keywords: Portfolio, Investment, Economic, Growth

\section{INTRODUCTION}

Indonesia economic growth recently is heading in uplifting direction. Central Bureau of Statistics in 2017, stated that Indonesia economic growth reached 5.01 percents at second quartal of 2017. It is due to the improving of the investment circumstances, both direct investment and stock exchange investment. Based on the Bank Indonesia, Capital Investment Coordinating Board, and Central Bureau of Statistics data stated that until 2016, previously the Indonesia economic growth was $+5.00 \%$. Through the Table 1 above, it can be seen that the direct investment average is $+67 \%$ and portfolio investment is $+32 \%$.

There were many empirical research clarified that the economic growth was closely connected with the investment. In China, Su and Liu [1], stated that FDI influenced the economic growth level in China. The same thing was found in Europe, Pegkas [2] claimed that FDI and share investment by foreign investor affected the economic growth of Europe. 
Iamsiraroj and Ulubaşoğlu [3] and Iamsiraroj [4] found that there were positive connection between economic FDI in different countries, because of the trade openness and financial market development, thus, it made FDI as the stimulant of development in different countries. Encinas-Ferrer and Villegas-Zermeño [5], in Argentina, Mexico, discovered that FDI marginally affected the economic growth of the country. Abbes, et al. [6] stated that FDI affected the domestic products gross in 65 countriess, however, the ccausality examination showed different result

Research done in the developing countries showed the same thing regarding the investment correlation and the economic growth of a country. Nistor [7] and Ali and Hussain [8], researched in Romania and Pakistan, concluded that FDI related positively with the GDP growth. So as Gui-Diby [9], stated that in different time had different impact; low interest rate period, the economic growth was high, and vice versa. In Pacific countries, Feeny, et al. [10] mentioned that the poor of domestic economic growth due to FDI acted as investment substitute in the countries. In Africa, Agbloyor, et al. [11] resumed that FDI took effect to the economic growth of Sahara.

In portfolio investment, Baek [12] suggested that PI in Latin America and Asia still had different point of view, one withdrew and another prompted. Ferreira and Laux [13] stated that investing in the share market, especially stock portfolio investment of local investor improved the economic growth of America as well. PI, in Latin America, caused the economic growth, whilst in Asia it was only temporarily dropped in money (hot money). That because of, in Asia, market changing frequently and unstable domestic economy factor. Albulescu [14], researched in Europe and West Europe, stated that both FDI and PI affected long-term economic growth.

Research in Indonesia showed the same thing upon the FDI and EG. Setyowati, et al. [15] and Rahayu (2012) remarked that there were causality of FDI and EG in Indonesia and in short-term, FDI affected the economic growth. However, Indrawati [16] claimed that the impact of FDI was lesser compared to the investment portfolio towards the economic growth. Ruslan [17] mentioned that there was inter-dependence between FDI and economic growth and some other macro factors, such as: exchange rate, and interest rate. Meanwhile Manullang and Hidayat [18] stated that in a long-term there was a correlation between FDI and economic growth in ASEAN countries, except for Singapore which had positive correlation of FDI and EG. Indonesia, Malaysia and Philippines had negative one. Another finding showed that there was no two ways correlation between FDI and EG.

\section{Research Method}

The Center Bureau of Statistics, Capital Investment Coordinating Board, and Bank Indonesia data were used for the research, which was accessed through www.bps.go.id, www.bi.go.id andwww.bkpm.go.id for period 2010:Q1 until 2016:Q4. After tabulated, we tested root unit to analyze the normality of the data, by applying the Augmented Dickey-Fuller Test (ADF test), to intensify the Vector Auto Regressive analysis accuration. The ADF test used the Mckinnon test as the repalcement of the $t$ table. It would be done the integrated level test if the data was not normal to find out the difference order of some stationer data.

Then, the lag optimum determination was done to detect the duration of exogen variables healing periodagainst the previous variables or other endogen variables. However, this matter was extremely determined by the short and long of a lag duration. Lag optimum determination 
was done by counting the Akaike's Information Criterion (AIC), Schwarz Criterion (SC) or Hannan Quinn (HQ). The lower the score of AIC, SC or HQ, the better the model specification. Therefore, the lag chosen in this research was the lowest score of AIC, SC and HQ models.

This research was using the correlation calibration of FDI, PI and EG, by applying the Vector Auto Regression method (VAR). Abustan and Mahyuddin [19] stated that VAR was considered as the simultaneous model yet the endogen variables in the model had been deliberated by entering the previous score which affected other endogen variables in the observed model. On the other hand, VAR could analyse the causality relation all of the economy variables and in establishing the structured economy model:

$\mathrm{EG}_{\mathrm{t}}=\mathrm{a}_{10}+{ }_{\mathrm{a} 11} \mathrm{EG}_{\mathrm{t}-1}+{ }_{\mathrm{a} 12} \mathrm{FDI}_{\mathrm{t}-1}+{ }_{\mathrm{a} 13} \mathrm{EG}_{\mathrm{t}-2}+{ }_{\mathrm{a} 14} \mathrm{FDI}_{\mathrm{t}-3}+\mathrm{e}_{1} \mathrm{FDI}_{\mathrm{t}}=\mathrm{a}_{20}+{ }_{\mathrm{a} 21} \mathrm{EG}_{\mathrm{t}-1}+{ }_{\mathrm{a} 22} \mathrm{FDI}_{\mathrm{t}-1}+{ }_{\mathrm{a} 23} \mathrm{EG}_{\mathrm{t}-2}+{ }_{\mathrm{a} 24} \mathrm{FDI}_{\mathrm{t}-}$ ${ }_{3}+\mathrm{e}_{2}$

$\mathrm{EG}_{\mathrm{t}}=\mathrm{a}_{30}+{ }_{\mathrm{a} 31} \mathrm{EG}_{\mathrm{t}-1}+{ }_{\mathrm{a} 32} \mathrm{PI}_{\mathrm{t}-1}+{ }_{\mathrm{a} 33} \mathrm{EG}_{\mathrm{t}-2}+{ }_{\mathrm{a} 34} \mathrm{PI}_{\mathrm{t}-3}+$

$\mathrm{PI}_{\mathrm{t}}=\mathrm{a}_{40}+{ }_{\mathrm{a} 41} \mathrm{EG}_{\mathrm{t}-1}+{ }_{\mathrm{a} 42} \mathrm{PI}_{\mathrm{t}-1}+{ }_{\mathrm{a} 43} \mathrm{EG}_{\mathrm{t}-2}+{ }_{\mathrm{a} 44} \mathrm{PI}_{\mathrm{t}-3}+\mathrm{e}_{4}$

Descriptions:

$\mathrm{EG}_{\mathrm{t}}=$ Economic growth in year $\mathrm{t}$

$\mathrm{FDI}_{\mathrm{t}}=$ foreign direct investmentin year $\mathrm{t}$

$\mathrm{PI}_{\mathrm{t}}=$ portfolio investmentin year $\mathrm{t}$

$\mathrm{EG}_{\mathrm{t}-\mathrm{n}}=$ Economic growth in year $\mathrm{t}-\mathrm{n}$

$\mathrm{FDI}_{\mathrm{t}-\mathrm{n}}=$ foreign direct investment in year $\mathrm{t}-\mathrm{n}$

$\mathrm{PI}_{\mathrm{t}-\mathrm{n}}=$ portfolio investment in year $\mathrm{t}-\mathrm{n}$

$\mathrm{a}_{10}, \mathrm{a}_{20}, \mathrm{a}_{30}, \mathrm{a}_{40}=$ Constanta

$\mathrm{e}_{1}, \mathrm{e}_{2}, \mathrm{e}_{3}, \mathrm{e}_{4}=$ Trangressor factors

The three equations above showed that the foreign direct investment and the economic growth were interplay one another in all observed variables, same thing happened with the portfolio investment and the economic growth. Causality correlation test between foreign direct investment, portfolio investment, and the economic growth were applying the Causality Granger test in the form of this vector auto regression (Gujarati, 1995).

\section{Results and Discussion}

\subsection{Stationer Data Test and Lag Optimum Selection}

Stationer data selection were using Augmented Dickey-Fuller on FDI,PI and EG with the eviews tools. The result could be seen on the Table 1 as follow:

Table 1. Unit Roots Test on the Level

\begin{tabular}{|c|c|c|c|c|c|c|}
\hline \multirow[t]{2}{*}{ Variables } & \multirow{2}{*}{$\begin{array}{c}\text { ADF } \\
\text { Scores }\end{array}$} & \multicolumn{3}{|c|}{ MacKinnon's Critical Scores } & \multirow[t]{2}{*}{ Prob } & \multirow{2}{*}{ Des } \\
\hline & & $1 \%$ & $5 \%$ & $10 \%$ & & \\
\hline EG & -1.979760 & -3.737853 & -2.991878 & -2.635542 & 0.2930 & TS \\
\hline FDI & 2.694524 & -3.737853 & -2.991878 & -2.635542 & 1.0000 & TS \\
\hline PI & -0.164298 & -3.711457 & -2.981038 & -2.629906 & 0.9316 & TS \\
\hline
\end{tabular}

Source: Processed Data, 2017; PS: data TS was not stationer 
The Augmented Dickey-Fuller(ADF) test results, Table 1, showed that all coefficient score variables on FDI, PI and EG were not stationer. That because of the coefficient score of FDI, PI and EG insignificant on the level under 5\%. For instance, The EG's ADF,-1.97960, lesser than MacKinnon's Critical Scores on the credibility level of -3.737853 . Further, Unit Roots Test was done on the $1^{\text {st }}$ difference, the result as follows:Unit Roots Test on the $1^{\text {st }}$ difference

\begin{tabular}{lcccccc}
\hline \multirow{2}{*}{ Variables } & \multirow{2}{*}{ ADF Scores } & \multicolumn{3}{c}{ MacKinnon's Critical Scores } & \multirow{2}{*}{ Prob } & \multirow{2}{*}{ Desc. } \\
\cline { 2 - 5 } & & $1 \%$ & $5 \%$ & $10 \%$ & & \\
\hline EG & -7.869607 & -3.711457 & -2.981038 & -2.981038 & 0.0000 & $\mathrm{~S}$ \\
FDI & -7.967371 & -3.711457 & -2.981038 & -2.629906 & 0.0000 & $\mathrm{~S}$ \\
PI & -7.313288 & -3.711457 & -2.981038 & -2.629906 & 0.0000 & $\mathrm{~S}$ \\
\hline
\end{tabular}

Source: Processed Data, 2017. NB. S (Stationer)

The Unit Roots Test (Table 2 ) on the $1^{\text {st }}$ difference defined that all coefficient variables, FDI, PI and EG, showed that the data had been stationer. This was showed by all the significantly probabilty scores on the level of 1 percent. After Stationer test, the lag optimum duration test was done, by choosing the smallest score of Akaike Information Criterion (AIC), Schwarz Criterion (SC), and Hannan-Quinn Criterion (HQ). Based on the test, the duration of lag optimum in this research was on the $3^{\text {rd }}$ lag.

Table 2. Lag Optimum Selection

\begin{tabular}{cccc}
\hline Lag & AIC & SC & HQ \\
\hline & & & \\
0 & 14.40511 & 14.55138 & 14.44568 \\
1 & 9.760228 & $10.34529 *$ & 9.922499 \\
2 & 9.559169 & 10.58302 & 9.843143 \\
3 & $8.902304 *$ & 10.36495 & $9.307981^{*}$ \\
\hline \multicolumn{5}{c}{ Source: Processed data, 2017 }
\end{tabular}

The result showed that SC scores on the $1^{\text {st }}$ lag, and HQ and AIC scores on the $3^{\text {rd }}$ lag. Thus, the lag score mostly appropriate with the model was the 3rd lag, on the LR score of 20.65297, FPE scores of 1.699895, AIC scores of 8.902304, and HQ scores of 9.307981. This meant that the acceleration or torpidity variables of this year influenced the previous year.The torpidity test showed the torpidity level of all variables to be stationer was lag 3 . It can be concluded that the economic growth, foreign direct investment, and portfolio investment were causality better on lag 3 .

This research was testing the Causality of FDI, PI and EG of Indonesia. The result showed that FDI and EG had bilaterally two ways relation. In other words, the increase of foreign capital flow would increase the economic growth of Indonesia. The same thing was happened with the correlation between EG and PI, the increase/reduction the past economic growth caused the increase/ reduction of capital flow in Indonesia. This because the investors or the foreign institutions expected positively towards Indonesia condition, i.e. society consumption level, companies profitability and controlled risk level.

The research found that PI and EG had two ways relation as well. This meant as the past portfolio investment activity at the stock exchange correlated with the present economic growth. The problem was, In Indonesia context, the economic growth was not responded rapidly with the height of portfolio investment, this could be seen on the significant score of 
10 percent. It meant that the investors were still playing prudent or playing wait and see towards the condition of Indonesia economic growth during this research.

The research implicated of the government of Indonesia FDI and EG had been working proper over the past decade due to numerous FDI foreign capital flow. It needed to be attempted to be guarded constantly so that the future policies would not affecting the economic growth. Another implication was the government of Indonesia, in this case Jokowi and Jusuf Kalla's administration, to be more pro active to persuade the foreign investors to invest in indonesia undoubtedly, both FDI investment and moreover the portfolio investment, because the economic growth of Indonesia was above of the world economic growth currently. This research had its limitation in data time period was very short and it only used two variables. The future research could be done by adding the period of time or crisis and non-crisis period. And it could be added other variables, i.e. foreign portfolio investment, domestic portfolio investment or other sectors of investment.

\subsection{The Correlation between Foreign Direct Investment and The Economic Growth}

This section explained the correlation between FDI and EG based on the vector autoregressive regression model (VAR). There were equation model established from the VAR test, as follows (Table 5):

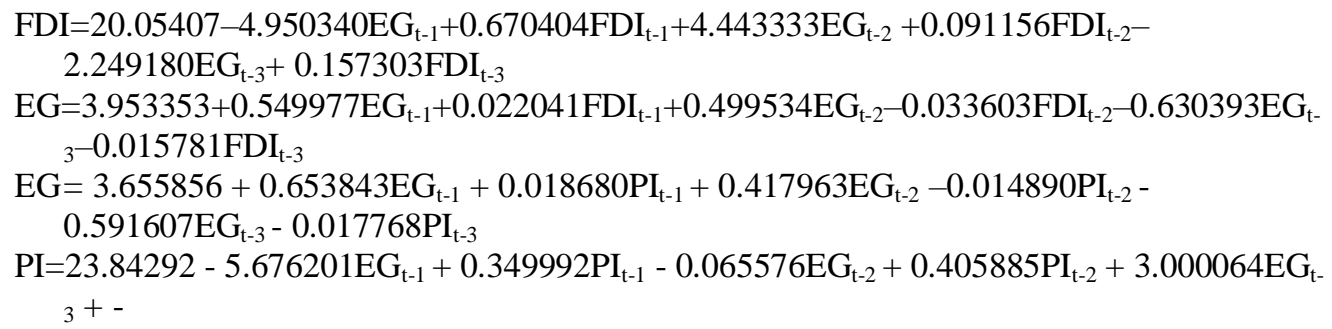

The first equation explained that the foreign direct investment (FDI) on lag 1, lag 2 and lag 3 were positive. This meant that each increasing of the FDI of 1 point base would increase the FDI score itself in the amount of the FDI coefficient on each lags. For example, on lag 1, the FDI coefficient was 0.670404, meaning every increment of FDI on lag 1 in the amount of 1 percent would increase the FDI itself of 0.670404. Meanwhile, EG on lag 1 had negative score, lag 2 had positive score, and lag 3 had negative score, which meant that EG on lag 1 and lag 3 increased in the amount of 1 point base that would reduce the FDI score. Whilst on lag 2 the increase of EG was followed by the increase of FDI.

Table 3. VAR Results between FDI and PI against EG in Indonesia

\begin{tabular}{cccccc}
\hline Variables & EG & FDI & Variables & EG & PI \\
\hline & 0.549977 & -4.950340 & & 0.653843 & -5.676201 \\
EG(-1) & $(0.17955)$ & $(2.01885)$ & EG(-1) & $(0.19553)$ & $(2.01927)$ \\
& & {$[-$} & & & {$[-$} \\
& {$[3.06301]$} & $2.45206]$ & & {$[3.34401]$} & $2.81101]$ \\
\hline
\end{tabular}




\begin{tabular}{|c|c|c|c|c|c|}
\hline $\mathrm{EG}(-2)$ & $\begin{array}{l}0.499534 \\
(0.23271) \\
\\
{[2.14659]}\end{array}$ & $\begin{array}{l}4.443333 \\
(2.61652) \\
\\
{[1.69819]}\end{array}$ & EG(-2) & $\begin{array}{l}0.417963 \\
(0.22486) \\
{[1.85876]}\end{array}$ & $\begin{array}{c}-0.065576 \\
(2.32223) \\
{[-} \\
0.02824]\end{array}$ \\
\hline EG(-3) & $\begin{array}{r}-0.630393 \\
(0.22351) \\
\\
{[-2.82043]}\end{array}$ & $\begin{array}{c}-2.249180 \\
(2.51307) \\
{[-} \\
0.89499]\end{array}$ & EG(-3) & $\begin{array}{r}-0.591607 \\
(0.19579) \\
\\
{[-3.02169]}\end{array}$ & $\begin{array}{l}3.000064 \\
(2.02197) \\
\\
{[1.48374]}\end{array}$ \\
\hline FDI(-1) & $\begin{array}{c}0.022041 \\
(0.02053)^{* *} \\
{[1.07343]}\end{array}$ & $\begin{array}{c}0.670404 \\
(0.23087) \\
{[2.90384]}\end{array}$ & $\mathrm{PI}(-1)$ & $\begin{array}{c}0.018680 \\
(0.02197)^{* *} \\
{[0.85032]}\end{array}$ & $\begin{array}{r}0.349992 \\
(0.22688) \\
{[1.54265]}\end{array}$ \\
\hline FDI(-2) & $\begin{array}{c}-0.033603 \\
(0.02453)^{* *} \\
{[-1.36993]}\end{array}$ & $\begin{array}{c}0.091156 \\
(0.27580) \\
{[0.33052]}\end{array}$ & PI(-2) & $\begin{array}{c}-0.014890 \\
(0.02116) * * \\
{[-0.70361]}\end{array}$ & $\begin{array}{r}0.405885 \\
(0.21855) \\
{[1.85716]}\end{array}$ \\
\hline FDI $(-3)$ & $\begin{array}{c}-0.015781 \\
(0.01802)^{* *} \\
{[-0.87550]}\end{array}$ & $\begin{array}{c}0.157303 \\
(0.20266) \\
{[0.77618]}\end{array}$ & $\mathrm{PI}(-3)$ & $\begin{array}{c}-0.017768 \\
(0.01994)^{* *} \\
{[-0.89111]}\end{array}$ & $\begin{array}{r}0.176625 \\
(0.20592) \\
{[0.85775]}\end{array}$ \\
\hline $\mathrm{C}$ & $\begin{array}{c}3.953353 \\
(1.40899) \\
{[2.80580]}\end{array}$ & $\begin{array}{c}20.05407 \\
(15.8423) \\
{[1.26586]}\end{array}$ & $\mathrm{C}$ & $\begin{array}{l}3.655856 \\
(1.70783) \\
{[2.14065]}\end{array}$ & $\begin{array}{r}23.84292 \\
(17.6374) \\
{[1.35184]}\end{array}$ \\
\hline $\begin{array}{l}\text { R- } \\
\text { squared }\end{array}$ & 0.897748 & 0.968974 & $\begin{array}{l}\text { R- } \\
\text { squared }\end{array}$ & 0.879327 & 0.988022 \\
\hline
\end{tabular}

On the second equation, the FDI coefficient score on lag 1 was positive, and on lag 2 and 3 were negative. It defined that on lag 1 the increase of 1 point base of FDI would increase EG of 0.022041. On lag 2 and lag 3, the increase of one point base of FDI will reduce EG score of 0.033603 on lag 2 and 0.015781 on lag 3. As for EG variables on lag 1 and lag 2 were positive and lag 3 was negative. This finding illustrated that the increase of 1 percent EG on lag 1 and lag 2 caused the increase of EG in the amount of 0.549977 on lag 1 and 0.499534 on lag 2. And the increase of 1 point base on lag 3, reduce the EG of 0.630393 .

The third equation was the correlation of PI and EG by VAR model. The result estimation

Table 4 VAR Results between FDI and PI against EG in Indonesiashowed that PI variables on lag 1, lag 2 and lag 3 were positive. This meant that on each lags whenever there were an escalation of PI, then it caused the increase of the PI coefficient, i.e. the coefficient PI score of lag 1 was 0.349992 , meaning if PI lag increase 1 percent, then the increase of PI was 0.349992. The EG on lag 1 and lag 2 were negative, whilst lag 3 was positive, which indicated that when there was the increase of EG on lag 1 and lag 2, one point base, will reduce the PI score of 5.676201 on lag 1 and 0.065576 on lag 2. The increase of EG one point base on lag 3, would increase the PI score of 3.000064 .

Lastly, the VAR estimation on the correlation of EG and PI showed that EG on lag 1 and lag 2 were positive and on lag 3 was negative. This defined that the increase of EG of one point base on lag 1 and lag 2 will increase the EG score of 0.653843 on lag 1 and 0.417963 on lag 2. And the increase of EG of one point base on lag 3 will reduce the EG of 0.591607. On 
the other hand, the PI variables on lag 1 showed positive, on lag 2 and lag 3 were negative. This meant that the increase of PI of 1 point base on lag 1 will raise the EG score of 0.018680 . And on lag 2 and lag 3, the increase, 1 point base, of PI will reduce the EG score of 0.014890 on lag 2 and 0.017768 on lag 3 .

\subsection{Granger Causality Test}

Granger Causality Test was done as form of causality relation test of foreign direct investment, portfolio investment, and economic growth. The result of the test generated variables which statistically influenced the two ways relation, in line one another. It could be seen on table 6 :

Table 5. Granger Causality Test

Null Hypotesis F-Statistic Prob.

FDI does not Granger Cause EG4.10530 $0.0220 * *$

EG does not Granger Cause FDI4.10530 $0.0220 * *$

PI does not GrangerCause EG4.56271 0.0369**

EG does not GrangerCause PI2.96756.0596*

It showed that there was two ways relation between FDI and EG, which can be seen through the probability of Granger Causality Test of FDI to EG or vice versa which had significantly score under $5 \%$ or 0.020 . The two ways relation explained that the changing pattern of FDI influenced the economic growth of Indonesia. This finding indicated that both past FDI and EG took effect on the score changing of present FDI and EG. Theoretically, it could be stated that the increase of EG in Indonesia could increase the amount of stock flows of FDI entering Indonesia. This because of the investors/ future investors considered that a country with good economic growth had small chance not to get the return or had small possiblity failed on investment. This finding was corresponding with stated by Rahayu (2012).

Furthermore, the causality relation was happened as well between the portfolio investment and the economic growth. The Granger Causality Test showed the correlation of PI and EG significantly on the level 5\%, whilst EG and PI had significant marginal score of $10 \%$. This indicated that the past PI and EG interplay the present PI and EG, However, the difference of the economic growth would not necessarily accelerate the share investment in the Indonesia Stock Exchange. That because Indonesia

\section{Conclusion}

This research was testing the Causality of FDI, PI and EG of Indonesia. The result showed that FDI and EG had bilaterally two ways relation. In other words, the increase of foreign capital flow would increase the economic growth of Indonesia. The same thing was happened with the correlation between EG and PI, the increase/reduction the past economic growth caused the increase/reduction of capital flow in Indonesia. This because the investors or the foreign institutions expected positively towards Indonesia condition, i.e. society consumption level, companies profitability and controlled risk level.

The research found that PI and EG had two ways relation as well. This meant as the past portfolio investment activity at the stock exchange correlated with the present economic 
growth. The problem was, In Indonesia context, the economic growth was not responded rapidly with the height of portfolio investment, this could be seen on the significant score of 10 percent. It meant that the investors were still playing prudent or playing wait and see towards the condition of Indonesia economic growth during this research.

The research implicated of the government of Indonesia FDI and EG had been working proper over the past decade due to numerous FDI foreign capital flow. It needed to be attempted to be guarded constantly so that the future policies would not affecting the economic growth. Another implication was the government of Indonesia, in this case Jokowi and Jusuf Kalla's administration, to be more pro active to persuade the foreign investors to invest in indonesia undoubtedly, both FDI investment and moreover the portfolio investment, because the economic growth of Indonesia was above of the world economic growth currently. This research had its limitation in data time period was very short and it only used two variables. The future research could be done by adding the period of time or crisis and non-crisis period. And it could be added other variables, i.e. foreign portfolio investment, domestic portfolio investment or other sectors of investment.

\section{References}

[1] Y. Su and Z. Liu, "The impact of foreign direct investment and human capital on economic growth: Evidence from Chinese cities," China Economic Review, vol. 37, pp. 97-109, 2016/02/01/ 2016.

[2] P. Pegkas, "The impact of FDI on economic growth in Eurozone countries," The Journal of Economic Asymmetries, vol. 12, pp. 124-132, 2015/11/01/ 2015.

[3] S. Iamsiraroj and M. A. Ulubaşoğlu, "Foreign direct investment and economic growth: A real relationship or wishful thinking?," Economic Modelling, vol. 51, pp. 200-213, 2015/12/01/ 2015.

[4] S. Iamsiraroj, "The foreign direct investment-economic growth nexus," International Review of Economics \& Finance, vol. 42, pp. 116-133, 2016/03/01/ 2016.

[5] C. Encinas-Ferrer and E. Villegas-Zermeño, "Foreign Direct Investment and Gross Domestic Product Growth," Procedia Economics and Finance, vol. 24, pp. 198-207, 2015/01/01/ 2015.

[6] S. M. Abbes, B. Mostéfa, G. Seghir, and G. Y. Zakarya, "Causal Interactions between FDI, and Economic Growth: Evidence from Dynamic Panel Co-integration," Procedia Economics and Finance, vol. 23, pp. 276-290, 2015/01/01/ 2015.

[7] P. Nistor, "FDI and Economic Growth, the Case of Romania," Procedia Economics and Finance, vol. 15, pp. 577-582, 2014/01/01/ 2014.

[8] N. Ali and H. Hussain, "Impact of Foreign Direct Investment on the Economic Growth of Pakistan," American Journal of Economics, vol. 7, pp. 163-170, 2017.

[9] S. L. Gui-Diby, "Impact of foreign direct investments on economic growth in Africa: Evidence from three decades of panel data analyses," Research in Economics, vol. 68, pp. 248-256, 2014/09/01/ 2014.

[10] S. Feeny, S. Iamsiraroj, and M. McGillivray, "Growth and Foreign Direct Investment in the Pacific Island countries," Economic Modelling, vol. 37, pp. 332-339, 2014/02/01/ 2014. 
[11] E. K. Agbloyor, A. Gyeke-Dako, R. Kuipo, and J. Y. Abor, "Foreign Direct Investment and Economic Growth in SSA: The Role of Institutions," Thunderbird International Business Review, vol. 58, pp. 479-497, 2016.

[12] I.-M. Baek, "Portfolio investment flows to Asia and Latin America: Pull, push or market sentiment?," Journal of Asian Economics, vol. 17, pp. 363-373, 2006/04/01/ 2006.

[13] M. A. Ferreira and P. A. Laux, "Portfolio flows, volatility and growth," Journal of International Money and Finance, vol. 28, pp. 271-292, 2009/03/01/ 2009.

[14] C. T. Albulescu, "Do Foreign Direct and Portfolio Investments Affect Long-term Economic Growth in Central and Eastern Europe?," Procedia Economics and Finance, vol. 23, pp. 507-512, 2015/01/01/ 2015.

[15] E. Setyowati, D. Wuryaningsih, and R. Kuswati, "Kausalitas Investasi Asing Terhadap Pertumbuhan Ekonomi: Error Correction Model," JESP: Jurnal Ekonomi \& Studi Pembangunan, vol. 9, pp. 69-88, 2008.

[16] Y. Indrawati, "Dampak Foreign Direct Investment dan Investasi Portofolio Terhadap Stabilitas Makroekonomi di Indonesia: Fenomena Global Imbalances," Prosiding Seminas, vol. 1, 2012.

[17] D. Ruslan, "Var Model Untuk Analisis Foreign Direct Investment Di Indonesia," Quantitative Economics Journal, vol. 3, 2015.

[18] H. A. Manullang and P. Hidayat, "Analisis Kausalitas antara FDI dan Pertumbuhan Ekonomi di ASEAN," Ekonomi dan Keuangan, vol. 2, 2015.

[19] A. Abustan and M. Mahyuddin, "Analisis Vector Auto Regressive (VAR) terhadap Korelasi Antara Belanja Publik dan Pertumbuhan Ekonomi di Sulawesi Selatan, Tahun 1985-2005," Jurnal Ekonomi Pembangunan: Kajian Masalah Ekonomi dan Pembangunan, vol. 10, pp. 1-14, 2009. 